\section{Comparative Investigation of Immune Globulins of Various Vertebrate Classes}

During the past fow years our knowledge of the immunoglobulins of man and mammals has been substantially extended. The method of making antiglobulin sora developed by Milgrom et al. in 1956 (ref. 1) has played a decisive part in this partioular connexion. As is well known, this method makes it possible to prepare antisera which react, in addition to $\gamma$-globulins (IgG, IgA, IgM), with complemental factors, if any ${ }^{2}$. Since our knowledge of non-mammalian immunoglobulins is limited ${ }^{3-10}$, I prepared (using a modification of Milgrom's method.' antisera to the globulins of mammals (horso, cattle, hog), birds (duck, goose), turtles (Testudo hermanni Gmelin), and fishes (Cyprinus carpio L., Tinca tinca (L.), Perca
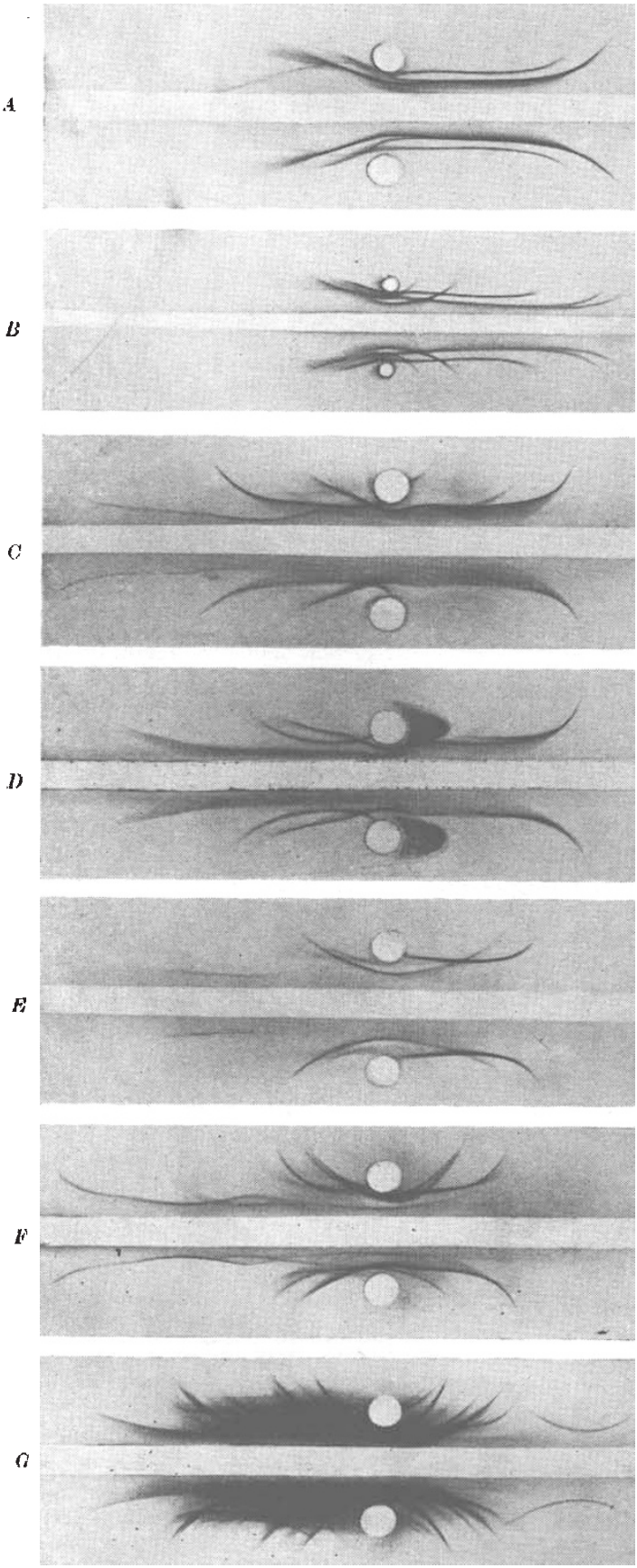

Fig. 1. Immunoelectrophoresis of 'immunoglobulins' (see text) from: $A$, duck; $B$, Testudo; C. Cyprinus; $D, T$ Thea; $E$, Ictalurus; $F$, Perc fuviatilis L., and Ictalurus nebulosus Le Sueur). The serum concentration used to bring about coupling with orythrocytes was chosen so that, for the mammals, only antibodies woro detectable against the $\gamma$-globulins during immunoclectrophoresis. In this connexion, distinct precipitate lines of the $\operatorname{IgG}$ and $\operatorname{IgM}$ globulins were always observed. Moreover, for both horse and hog a weak line was obscrved corresponding to the IgA globulin. The antisora prepared against the globulins of goose and duck showed wide identity during immunoelectrophoresis. Two parallel lines were found that could be assigned to the IgG and IgM globulins (Fig. 1A). Clearly visible is a splitting up of the IgG line in the anodic region.

The immunoelectrophorotic analysis of the antiserum against turtle globulins yielded 4-5 precipitin lines (Fig. $1 B$ ). Of these, the IgG line shows, at both ends, a splitting that cannot be simply attributed to ageing of the serum. In addition to the typical IgM line two distinct lines were also present in the $\alpha_{2}$ region; it is possible that these correspond to complemontal factors.

Whereas the analysis of the antisera against mammalian, bird, and turtle globulins shows a certain conformity, the fish globulins differ both from the others and from one another to a considerable extent. It is true that lines corresponding to the $\operatorname{IgG}$ globulin are thus found for Cyprinus, Tinca, and Ictalurus, but they are lacking for Perca (Figs. $1 C-F$ ). Also, the immunoelectrophoresis with one antiserum against the complete serum proteins of Perca confirms the absence of a typical IgG fraction (Fig. $1 G$ ). Here, only a faint but entirely uniform fraction is found in the cathodic region.

'Tho immune sera prepared using Milgrom's method precipitate for fishes, quite a large number of fractions extending into the $\alpha$-globulin region, and for Perca and Cyprinus even into the pre-albumin region. Although further investigations will be required in order to clarify which of these fractions are genuine immunoglobulins, the presont results already give some indication of the strong heterogeneity of the immunoglobulins for fishes.

\section{Zoology Institute,} H. Ambrosius

University of Leipzig, Germany.

${ }^{1}$ Milgrom, F., Luszezynski, T., and Dubiski, S., Nature, 177, 329 (1956).

${ }^{2}$ Fairley, G. H., and Harris, G., Vox Sang., ", 175 (1962).

3 Uhr, J. W. Finkelstein, M. S., and Franklin, E. C., Proe. Soc. Exp. Biol. and Med., , 1il, 13 (1962).

${ }^{4}$ Benedict, A. A., Brown, R. J., and Hersh, R., Proc. Soc. Exp. Biol. and Med., 113, $136(1963)$.

${ }^{5}$ Grey, H. M., J. Immunol., 91, 819 (1063); Proc. Soc. Exp. Biol. and Med. 113,963 (1963).

5 Ambrosius, H., and Lehmann, R., Zt. Immun- u. Allergieforschg., 128, 81 (1964); ibid.' (in the press).

Ashbach, N. E., Finstad, J., Sarnecki, J. C., and Pollara, B., Fed. Proc., 23, 346 (1964).

${ }^{8}$ Finstad, J., and Good, R. A., J. Exp. Med, 120, 1151 (1964).

- Good, R. A., and Papermaster, B. W., Adv. Immunol, 4, 1 (1964).

${ }^{20}$ Papermaster, 1. W. W., Condic, R. M., Finstad, J., and Good, R. A., J. Exp. Med., 119, 105 (1964).

\section{PATHOLOGY}

\section{Leptomeningeal Sarcomata and Gliomata induced in Rabbits by Rous Sarcoma Virus}

Much has beon written in recent years about the ability of Rous sarcoma virus (RSV) to induee malignant neoplasms in mammals.

Heterozygotic albino mice ${ }^{1}$, rats ${ }^{1-6}$, hamsters ${ }^{7,8}$, guineapigs $^{9}$, and monkeys ${ }^{10}$ wore found to be susceptible to the Carr-Zilber ${ }^{3}$ strain or Schmidt-Ruppin strain of RSV (ref. 1). Recontly, Bryan ${ }^{11}$ strain and Mill-Hill (Harris) ${ }^{12}$ strain of RSV were found to be oncogenic for hamsters ${ }^{13,14}$.

Zilber ${ }^{15}$ was the first to inoculate rabbits with Rous sarcoma virus. Numerous fibrous nodules and punctate haemorrhages in various organs were observed following repeated subcutaneous inoculation of Carr-Zilber strain RSV. Usually the fibrous nodules underwent reabsorption $^{16}$. Later, Ahlström ${ }^{17}$ subcutaneously inoculated rabbits 